\title{
The impact of non-performing loans on bank profitability and lending behavior: Evidence from Vietnam
}

\author{
NGUYEN THI HONG VINH \\ Banking University of Hochiminh City - vinhnth@buh.edu.vn
}

\begin{abstract}
ARTICLE INFO ABSTRACT
Article history:

Received:

Aug., 15, 2016

Received in revised form:

Apr., 28, 2017

Accepted:

June, 30, 2017

Keywords:

Non-performing loan

Profitability

The aim of this study is to investigate the impact of non-performing loans on profitability and lending behavior, using an empirical framework that examines whether an increase of NPLs can lead banks to reduce their profitability and lending activity. To account for profit and lending persistence, the paper applies the Generalized Method of Moments technique for dynamic panels using bank-level data for 34 Vietnamese commercial banks over the period from 2005 to 2015. Throughout the whole sample, we find some evidence that the nonperforming loan has a statistically significant negative effect on Vietnamese commercial banks profitability and lending behavior. The estimation results also show that other bank specific and macroeconomic determinants affect bank profitability and lending behavior significantly in the anticipated way. These findings will be helpful for bank managers and policy makers to improve the performance and lending behavior of Vietnamese commercial banks.
\end{abstract}

Lending behavior

GMM estimation 


\section{Introduction}

The issue of non-performing loans (NPLs) has recently become a cause for concern in Vietnam. The ratio of NPLs in Vietnam sharply increased in the year of 2012. SBV reported that the ratio of NPLs to total loans was $4.3 \%$ by the third quarter of 2012. IMF and World Bank ${ }^{1}$ (2014) estimate the ratio of NPLs for
Vietnam banking sector was $12 \%$ by the end of 2012. Meanwhile, Moody ${ }^{2}$ (2014) showed that the ratio of NPLs to total assets in Vietnam was $15 \%$ by February 2014. Table 1 summarizes the average NPLs, profitability (ROA), and loan growth rate (LGR), reflecting a upward trend in NPLs and downward changes in ROA and LGR for Vietnamese banking system from 2005 to 2015 .

\section{Table 1}

Rates of non-performing loans, return on assets, and loan growth for Vietnamese banks during 2005-2015 (\%)

\begin{tabular}{lcccccccccc}
\hline & 2005 & 2007 & 2008 & 2009 & 2010 & 2011 & 2012 & 2013 & 2014 & 2015 \\
\hline NPLs & 1.799 & 1.141 & 2.053 & 1.663 & 2.008 & 2.305 & 3.653 & 3.166 & 2.396 & 1.780 \\
ROA & 1.678 & 1.651 & 1.284 & 1.571 & 1.263 & 1.217 & 0.862 & 0.644 & 0.627 & 0.488 \\
LGR & 44.118 & 165.995 & 23.319 & 92.457 & 43.973 & 23.063 & 18.034 & 35.888 & 16.421 & 25.238 \\
\hline
\end{tabular}

Source: Vietnamese commercial banks' annual reports, author's own estimations

Although the impact of NPLs on bank behavior is of crucial importance in Vietnam, there have been few studies to address this issue. Besides, studies on Vietnamese banks mainly exploited static panel data methods such as Random Effects Model and Fixed Effects Model. The static panel data methods may lead to bias in results because they have not deal with the endogenous issue. The paper thus applies the dynamic panel data to examine the relation between NPLs and profitability and loan growth. The research results allow the bank's management to focus on issues that

\footnotetext{
${ }^{1}$ see World Bank \& IMF (2014). Financial sector assessment program - Vietnam. June 2014
}

will let them enhance the bank's overall profitability and lending activity in the future. This also helps policy makers to find suitable banking policies to deal with the non-performing loan problem for commercial banks.

The rest of the paper is structured as follows. Section 2 looks at previous researches on the impacts of non-performing loans on profitability and credit growth. While Sections 3 and 4 provides the method employed and describes the research data respectively, the empirical results are presented in Section 5. Finally, Section 6

\footnotetext{
${ }^{2}$ see Moody's Investors Service (2014). Vietnam banking system outlook. February 2014.
} 
utters concluding remarks and draws a few implications.

\section{Literature review}

As indicated in the literature concerning the impact of NPLs on banks profitability and lending behavior, an increase in NPLs would lead to higher provisions, lower profitability, and considerable erosion in bank capital. This may cause negative effects on further lending. The topic attracts a considerable degree of attention according to the stage of business cycle and banks' specific characteristics (Le, 2016; Athanasoglou et al., 2008; Demirgu"c,Kunt, \& Huizinga, 1999; Cucinelli, 2015; Hou \& Dickinson, 2007).

\subsection{Effects of non-performing loans on bank profitability}

Does a higher level of NPLs refer to a lower profitability for banks? The relationship between NPLs and profitability is one of the central topics in banking studies because of the potential implications for regulatory policies. A number of studies found that failing banks tend to have lower efficiency and high ratios of problem loans (Berger \& Humphrey, 1992; Wheelock \& Wilson, 1994). A good number of other studies detected negative relationships between profitability and problem loans even among the ones which do not fail (Kwan \& Eisenbeis, 1995; Hughes \& Moon, 1995; Karim, 2010).

In addition, studies on bank profitability recently took into account asset quality, and specifically NPLs. Athanasoglou et al.
(2008) showed that the poor quality of loans reduces interest revenue, thus confirming that NPLs has a negative effect on bank profitability. A number of researchers found that NPLs lead to lower profitability in the banking sector (Altunbas et al., 2000, Fan \& Shaffer, 2004; Girardone et al., 2004). The findings support the hypothesis that the efficient banks are better at managing their credit risk as proposed by Berger and DeYoung (1997). Banker et al. (2010) also mentioned that once the importance of nonperforming loans is ambiguous, banks fear that their lending behavior will suffer disadvantages, and if an increase in NPLs exceeds expected levels, this will impact negatively on the bank profitability.

Using a panel dataset for 14 Korean commercial banks over the 1995-2005 period, Banker et al. (2010) concluded that the NPL ratio has a negative impact on bank productivity. Marius (2011) examined the relationship between NPL and efficiency for the Central and Eastern European banking sector between 2004 and 2009. Their findings showed that this relationship is statistically significant and negative, which suggests that banks should limit NPLs as a solution to enhance bank's efficiency. Trujillo-Ponce's (2013) study produced the same results in evaluating determinants of productivity among Spanish commercial banks from 1999 to 2009. By using unbalanced panel data and GMM estimation for analyzing the impact of NPLs for the case of 89 banks with 697 observations, the empirical results indicated that NPLs have negative effects on ROA at a significance level of 5 percent and ROE at a significance 
level of 1 percent.

By evaluating performance through control of risk factors and asset quality of Japanese commercial banks in 1993-1996, Altunbas et al. (2000) confirmed that there exists a negative relationship between NPLs ratio and performance, and after controlling for risk factors, banks tend to suffer a reduction in operating efficiency of scale due to cost cutting. This finding is consistent with the studies of Hughes \& Mester (1993) conducted on banks in the US and Girardone et al. (2004). In Vietnam, Pham (2013) evaluated the impact of NPLs on the profitability of Vietnamese commercial banks between 2005 and 2012. The results indicated that NPLs has a significant and negative correlation with banks' profitability ratio.

The earlier empirical papers also provided considerable evidence to support the hypotheses relating to the effects of bank-specific characteristics on profitability, such as capital, bank size, loan growth, and competition. The structureconduct-performance hypothesis refers to the relationships among capital, competition, and profitability. The results of such research show that operating performance is significantly related to market structure. Market structure, which refers to the degree of market concentration within an industry, represents the degree of competition within a specific industry. For example, Heggestad (1977), Short (1979), and Akhavein et al. (1997) verified that, within a financial system characterized by less competition, firms tend to have larger scales of operation, and this in turn leads to a higher degree of market concentration and profits (Lee \& Hsieh, 2013; Hannan \& Berger, 1991; Neumark \& Sharpe, 1992; Demirgüç-Kunt \& Huizinga, 1999). In addition, bank size is proved to yield a positive effect on profitability (DemirgüçKunt \& Huizinga, 1999; Goddard et al., 2011).

\subsection{Effects of non-performing loans on bank lending behavior}

The non-performing loan has been concerned as one of the most critical factors causing reluctance for the banks to provide credit. In a high NPL condition, banks increasingly tend to tighten credit standards in response to deterioration in credit quality (Berger \& Udell, 2004). In addition, the high level of NPLs requires banks to raise provision for loan loss that leads to decrease in banks' revenue and reduces the funds for new lending (Hou \& Dickinson, 2007). The financial accelerator effect also refers to the effects of NPLs on banks' lending behavior. This theory relates to borrowers' equity position (or net worth) which influences their access to credit. This also explains bank lending behavior and its relationship with the cyclical fluctuations in the economy. When a net worth of a firm is improved, the greater it is, the lower the external finance premium as lenders assume less risk when lending it to high net worth agents during business upturns. An adverse shock that lowers borrowers' current cash flows leads to a decline in their net worth and raises external finance premium. The increase in borrowers' cost of financing will discourage their desires to undertake more 
investment projects and consequently affect the demand for credit, amplifying the effect of the initial shocks (Bernanke et al., 1994; Kiyotaki \& Moore, 1995; Le, 2016).

The relationship between loan growth and bank risk, especially credit losses, has been studied at the macroeconomic level in several strands of the literature (Keeton, 1999; Borio et al., 2002), but there are few studies which focus on the relationship between NPLs and bank lending behavior. Based on a sample of listed banks in China, Lu et al. (2005) discussed the relationship between banks' lending behavior and NPLs. Their findings indicated that the banking sector presents a bias in China, as banks are more likely to offer loans to state-owned firms, even though these can entail a high credit risk. Borio et al. (2002) argued that problem loans increase as a result of firms' and households' financial distress for Spanish banks during recession. This research also implies bank lending is strongly procyclical, and that in periods of expansion banks are more likely to grant loans to firms with low credit quality. This leads to future problems and default, typically during downturns, with an estimated time lag of approximately three years. Tomak (2013) investigated the determinants of banks' lending behavior on a sample of Turkish banks, exploring a significant relationship between NPLs and banks' lending behavior among state-owned banks and verifying the negative impact of NPLs on the growth of total loans.

Foos et al. (2010) analyzed the effect of loan growth on the NPLs of individual banks. They found that loan growth has a negative impact on risk-adjusted interest income, which suggests that loan growth is a significant driver of the riskiness of banks. Amador et al. (2013) examined the relationship between abnormal loan growth and bank risk-taking behavior. Their findings indicated that abnormal credit growth over a prolonged period of time would lead to an increase in banks' riskiness, accompanied by a reduction in solvency and an increase in the ratio of NPLs. Several studies concluded that excessive credit growth leads to the development of asset price bubbles. Borio et al. (2002) and Borio and Drehmann (2009) demonstrated that excessive credit growth is the main factor of a financial crisis in some cases where it appears that the flow of loans stays high for the remainder of the year.

In short, most of the earlier empirical investigations suggest that reduction of banks' credit relates to NPLs. As the majority of the existing studies on the impact of NPLs on bank lending behavior have contextualized the issue in advanced countries, this study attempts to fill the literature gap by examining the impact of NPLs on profitability and lending behavior in an emerging country. Additionally, the current research tends to apply a singleequation framework and the VAR model or fixed effect regression to the panel data. However, this methodology may encounter dynamic panel bias and fail to capture reverse causality. The dynamic panel techniques are thus adopted to address these problems and analyze the panel data, designed to check the persistence of profits and lending behavior. 


\section{Methodology}

This paper applies the two-step dynamic panel data approach suggested by Arellano and Bover (1995) and Blundell and Bond (2000) to address potential endogeneity, heteroskedasticity, and autocorrelation problems in employing the data (Doytch \& Uctum, 2011). The dynamic panel data model provides a more flexible variancecovariance structure under the moment conditions. The GMM approach is better than traditional OLS in examining financial variable movements. For instance, Driffill et al. (1998) indicated that a conventional OLS analysis of the actual change in the short rate on the relevant lagged term spread yields coefficients with some wrong signs and wrong size. The research also follows Windmeijer's (2005) finite-sample correction to report standard errors of the two-step estimation, without which those standard errors tend to be severely downward biased.

The study adopts the dynamic panel data approach and GMM to estimate the parameters. Although there is correlation or heteroskedasticity among the equations, the estimated standard deviation still appears to be robust. Therefore, the independent variable with lagged periods is included in Eqs. (1) and (2) as shown below. Besides the dynamic panel data, the model that establishes the impact of NPLs on profitability and lending behavior is based on the previous literature. According to the earlier findings and this study' research objective, the author modifies the equations of Le (2016), Altunbas et al. (2007), Casu and Girardone (2006), and Goddard et al. (2004) to capture the relationship between NPLs and profitability and lending behavior. These relationships can be specified as follows:

$$
\begin{aligned}
& \pi_{i t}=\gamma_{2} \pi_{i t-1}+\varphi_{2} M_{t}+\lambda_{2} N P L_{i t}+ \\
& \pi_{2} F_{i t}+\varepsilon_{2, i t} \\
& L G R_{i t}=\gamma_{4} L G R_{i t-1}+\varphi_{4} M_{t}+ \\
& \lambda_{4} N P L_{i t}+\pi_{4} F_{i t}+\varepsilon_{4, i t}
\end{aligned}
$$

in which $t$ and $i$ are the time period and bank, respectively, $\varepsilon_{1,2,3,4, i t}=\eta_{t}+v_{i t}$ and $\eta_{i t}$ denote an unobserved bank-specific effect, and $v_{i t}$ is the idiosyncratic error term.

Eqs. (1) and (2) are designed to examine the impacts of NPLs on bank profitability and bank lending behavior, respectively. $N P L_{i t}$ is the ratio of NPLs to gross loan; $\pi_{i t}$ refers to the $i$ th bank's profitability in year $t$, proxied by return on assets (ROA). Also, $L G R_{i t}$ refers to the $i$ th bank's lending behavior in year $t$, proxied by the percentage difference in total gross loan. The vector of explanatory variables includes bank-specific variables $(\mathrm{F})$, including the capital proxied by the ratio of equity on total assets, the liquidity presented by the ratio of loan to deposit, degree of banking competition ( $\mathrm{Fu}$ \& Heffernan 2009) is measured by the degree's proxy CR4 (the four-bank concentration ratio), and the HHI (Herfindahl-Hirschman index), bank ownership proxied by dummy variables, and macroeconomic factor (M). It is crucial to consider the persistence of profitability through the dynamic panel model because banks are always accompanied by the 
feature of profitability persistence (Lee et al., 2013). This is also clearly a concern in the studies of bank lending behavior that the loan growth variable displays high levels of persistence (e.g., Le, 2016; Foos et al., 2010). Previous investigations showed that bank-specific variables are likely to be potentially endogenous (Athanasoglou et al., 2008) and that some other independent variables are not strictly exogenous. Using GMM estimation, therefore, involves instrumenting the endogenous variables, which provides consistent estimates. The paper uses the lags of right hand side variables in the equations as instruments. The two-step estimation is used because it is asymptotically more efficient than the onestep estimation for the presence of heteroskedasticity and serial correlation (Blundell \& Bond, 1998). In this estimation, the Hansen J-test is used to test the validity of instrument sets, and the Arellano-Bond test is applied to check the absence of second-order serial correlation in the first differenced residuals.

Employed as related internal control variables are equity to total assets (ETA), loan to deposit (LTD), loan growth (LGR), total assets (TA), and competition ratios such as HHI and CR4 (Casu \& Girardone, 2006; Short, 1979; Lee \& Hsieh, 2013; Le, 2016). The coefficients of ETA, TA, LDR, CR4, and HHI are expected to be positively correlated with profitability and lending behavior. A higher value of concentration refers to less competition. Thus, banks enjoy a higher market advantage, such as economies of scale or scope, with the result of greater profits. Therefore, the $\alpha_{1}$ coefficient should be positive. On the contrary, NPL is expected to be negatively associated with profitability and lending behavior.

Two macro control variables set as related external control variables comprise inflation (INF) and GDP growth rate (GDP). The coefficients of INF and profitability and lending behavior are expected to be negative because banks may charge customers more in high-inflation countries, yet at the same time they face due loans that are shrinking. A higher growth economy may imply that banks can generate more profitability. Thus, the coefficients of GDP and profitability and lending behavior are expected to be positive. 


\section{Table 2}

Summary of explanatory variables

\begin{tabular}{|c|c|c|c|c|}
\hline \multirow[t]{2}{*}{ Classification } & \multirow[t]{2}{*}{ Variable } & \multirow[t]{2}{*}{ Description } & $\begin{array}{l}\text { Expected } \\
\text { sign }\end{array}$ & $\begin{array}{l}\text { Expected } \\
\text { sign }\end{array}$ \\
\hline & & & ROA & LGR \\
\hline \multirow{2}{*}{$\begin{array}{l}\text { Independent } \\
\text { variables }\end{array}$} & ROA & Net income after tax to average assets & & + \\
\hline & LGR & $\begin{array}{l}\text { Percentage change in gross loan } \\
\text { provided to customers }\end{array}$ & + & \\
\hline \multirow{9}{*}{$\begin{array}{l}\text { Bank-level } \\
\text { variables }\end{array}$} & NPL & Non-performing loan to gross loan & - & - \\
\hline & ETA & The ratio of equity on total assets & + & + \\
\hline & LDR & Ratio between loan to customer deposit & + & + \\
\hline & TA & Logarithm of bank's total asset & + & + \\
\hline & HHI & The concentration of a specific industry & & \\
\hline & & $\mathrm{HHI}=\sum_{\mathrm{j}=1}^{\mathrm{n}} \mathrm{MS}_{\mathrm{j}}^{2}$ where $\mathrm{Sj}$ & & \\
\hline & & $\begin{array}{l}\text { denotes the market share of the jth bank } \\
\text { using total assets as a proxy for market } \\
\text { share }\end{array}$ & + & + \\
\hline & CR4 & $\begin{array}{l}\text { The share of the loan market controlled } \\
\text { by the four largest banks, CR } 4= \\
\sum_{\mathrm{j}=1}^{4} \mathrm{MS}_{\mathrm{j}}\end{array}$ & + & + \\
\hline & OWN & $\begin{array}{l}\text { The dummy variable reflects the effects } \\
\text { of different ownership types on banks' } \\
\text { profit and loan growth. The dummy } \\
\text { OWN1, OWN2, OWN } 3 \text { variables take } \\
\text { value of one if the percentage of } \\
\text { shareholder ratio are respectively } 10 \% \text {, } \\
25 \% \text {, and } 50 \% \text {, and zero otherwise. }\end{array}$ & relevant & relevant \\
\hline \multirow{2}{*}{$\begin{array}{l}\text { Macroeconomic } \\
\text { variables }\end{array}$} & GDP & Real GDP annual growth rate & + & + \\
\hline & INF & $\begin{array}{l}\text { Inflation, average consumer price } \\
\text { (percentage change) }\end{array}$ & - & - \\
\hline
\end{tabular}




\section{Data description}

This study analyzes a panel of 34 Vietnamese commercial banks over the time period from 2005 to 2015. The dataset consists of an unbalanced panel of banks, since not all banks enter the sample in every year. Bank specific data are obtained from the banks' annual reports, which include income statements and balance sheet information. As in other similar studies, unconsolidated statements are used; this choice prevents relevant differences in profit and loss statements and balance sheets of headquarters and subsidiaries from negating each other (García-Herrero et al., 2009; Trujillo-Ponce, 2013). The macroeconomic data come from IMF-IFS website. The sample of 34 Vietnamese commercial banks is listed in the Appendix.

\section{Table 3}

Descriptive statistics of variables

\begin{tabular}{lccccc}
\hline & Mean & Min & Max & Std. dev. & Obs. \\
\hline NPL & 2.172 & 0.000 & 14.856 & 1.683 & 357 \\
ROA & 1.137 & 0.000 & 4.19 & 0.799 & 357 \\
TA & 17.343 & 11.884 & 20.562 & 1.648 & 357 \\
LGR & 53.375 & -40.811 & 1131.728 & 109.780 & 357 \\
ETA & 12.566 & 0.514 & 71.206 & 9.971 & 357 \\
LDR & 66.910 & 15.333 & 206.2 & 27.322 & 357 \\
HHI & 0.099 & 0.0715 & 0.170602 & 0.0306 & 357 \\
CR4 & 0.561 & 0.456 & 0.796148 & 0.105 & 357 \\
GDP & 6.304 & 5.250 & 8.440 & 0.913 & 357 \\
INF & 9.501 & 0.630 & 23.120 & 5.978 & 357 \\
\hline
\end{tabular}

Table 3 provides a summary of statistics for the maximum, minimum, average, and standard deviation of the variables used to estimate the impacts of NPLs on profitability and credit growth. The statistics are calculated from yearly data in which all variables are expressed in percentage. From these figures, it can be observed that the average of NPLs in the research period is $2.172 \%$ of total loans. The loan to deposit is very large $(66.910 \%)$. Besides, ROA ranges from $0.00 \%$ to $4.19 \%$, which shows the difference in profitability of different banks. Table 4 shows the correlation coefficients between variables, which are relatively low except for the variable pair of HHI-CR4. This analysis appears to support the hypothesis that each independent variable has its own specific information value in its ability to explain bank profitability and 
lending behavior.

Table 4

Correlation matrix of variables

\begin{tabular}{lccccccc}
\hline & ROA & LGR & NPL & ETA & LTD & TA & HHI \\
\hline ROA & 1.000 & & & & & & \\
LGR & 0.1989 & 1.0000 & & & & & \\
NPL & -0.321 & -0.209 & 1.000 & & & & \\
ETA & 0.331 & 0.064 & -0.076 & 1.000 & & & \\
LDR & 0.150 & -0.040 & -0.061 & 0.255 & 1.000 & & \\
TA & -0.434 & -0.216 & 0.251 & -0.543 & -0.302 & 1.000 & \\
HHI & 0.245 & 0.124 & -0.237 & 0.190 & 0.237 & -0.548 & 1.000 \\
CR4 & 0.278 & 0.148 & -0.221 & 0.208 & 0.246 & -0.579 & 0.985 \\
OWN1 & 0.198 & 0.045 & -0.084 & 0.325 & -0.001 & -0.315 & -0.044 \\
OWN2 & -0.095 & 0.079 & 0.052 & -0.086 & -0.069 & -0.077 & 0.014 \\
OWN3 & -0.134 & -0.068 & 0.172 & -0.274 & 0.089 & 0.357 & 0.013 \\
GDP & 0.194 & 0.129 & -0.253 & 0.112 & 0.161 & -0.419 & 0.494 \\
INF & 0.149 & -0.075 & 0.032 & 0.075 & 0.000 & -0.114 & -0.049 \\
\hline & CR4 & OWN1 & OWN2 & OWN3 & GDP & INF & \\
\hline CR4 & 1.000 & & & & & & \\
OWN1 & -0.047 & 1.000 & & & & & \\
OWN2 & 0.014 & -0.161 & 1.000 & & & & \\
OWN3 & 0.019 & -0.626 & -0.167 & 1.000 & & & \\
GDP & 0.551 & -0.035 & 0.009 & 0.005 & 1.000 & & \\
INF & 0.004 & -0.020 & 0.008 & 0.024 & -0.170 & 1.000 & \\
\hline & & & & & & & \\
\hline
\end{tabular}

\section{Empirical results}

\subsection{Effect of non-performing loans on} bank profitability

The estimation results are presented in Tables 5 and 6, which report the respective impacts of NPLs on bank profitability and lending behavior from the empirical models of Eqs. (1) and (2). Columns 1 and 2 of Table 5 indicate the effects of the two different degrees of competition proxies (CR4 and $\mathrm{HHI}$ ) and the dummy variable along with those of control variables on ROA. Table 3 shows that the coefficient of NPLs on profit is significantly negative at a $1 \%$ level. The negative relation is consistent with the findings of Athanasoglou (2008), Demirgu“c,-Kunt and Huizinga (1999), and 
Le (2016). Thus, the trend of profitability in the Vietnamese banking industry is downward and is accompanied by increasing NPLs. This means that the poor quality of loans reduces interest revenue and increases provisioning cost. This also suggests that in order to maximize profits, banks should improve the screening and monitoring of the risk of loan defaut (Karrminsky \& Kosstrov, 2014).

Table 5 reveals that the coefficient value of profit persistence, which is measured by L.ROA, is significantly positive at 0.2432 , which shows that the Vietnamese banks have persistence of profit. The other findings from Table 3 demonstrate that considering either the CR4 or HHI statistic, the coefficient of the effect of bank competition on profit is significantly positive at a $5 \%$ level. The positive relation is consistent with the finding of Berger et al. (2010), and the market power of the SCP hypothesis appears to hold: the more concentrated (less competition) the market, the more profitable the banks. Among the other control variables, the effects of the ratio of loans to deposit, the burden ratio, and total assets on bank profit are significantly negative, while the real GDP growth rate has a positive impact on profit.

The findings also indicate that the Hansen and serial-correlation tests do not reject the null hypothesis of correct specification, which means that the research has valid instruments and no serial correlation.

\section{Table 5}

Estimation results of non-performing loans and profitability

\begin{tabular}{lcc}
\hline & \multicolumn{2}{c}{ ROA } \\
\cline { 2 - 3 } L.ROA & $(1)$ & $(2)$ \\
NPL & $0.2831 * * *(0.0718)$ & $0.2274 * * *(0.0125)$ \\
ETA & $-0.2824 * * *(0.0441)$ & $-0.1673 * * *(0.0214)$ \\
LGR & $0.0216^{* * *(0.0033)}$ & $0.0054 *(0.0451)$ \\
TA & $0.0015^{* * *(0.0003)}$ & $0.0019 * *(0.0003)$ \\
LDR & $-0.3149 * *(0.0606)$ & $-0.3287 * *(0.0699)$ \\
Own1 & $0.0006^{* * *(0.003)}$ & $0.0007 *(0.0003)$ \\
Own2 & $0.1220 * *(0.5438)$ \\
Own3 & $-0.0765 *(0.1487)$ \\
HHI & & $-0.0736 *(0.3511)$ \\
CR4 & $0.2379 * *(0.0651)$ & \\
GDP & & $0.4198 * *(0.9821)$ \\
INF & $0.0418 * * *(0.0193)$ & $0.0482 * * *(0.0783)$
\end{tabular}




\begin{tabular}{lcc}
\hline & \multicolumn{2}{c}{ ROA } \\
\cline { 2 - 3 } & $(1)$ & $(2)$ \\
\hline CONS. & $-1.4958 * * *(0.0370)$ & $-0.2842 * * *(0.2319)$ \\
No. of Obs. & 323 & 323 \\
Banks & 34 & 24 \\
No. of iv. & 22 & 0.000 \\
Pro>chi2 & 0.000 & 0.451 \\
Hansen test & 0.507 & 0.022 \\
AR(1) & 0.009 & 0.359 \\
AR(2) & 0.483 & \\
\hline
\end{tabular}

Notes: $* * *, * * * *$ and $* *$ denote significance levels of $1 \%, 5 \%$, and $10 \%$ respectively. Standard errors are in parentheses. The HHI variable is removed from specifications (1) and (2) to avoid the multicollinearity problem as it is highly correlated with CR4.

\subsection{Effect of non-performing loans on} banks' lending behavior

Table 6 exhibits the empirical results for NPLs and banks' lending behavior (LGR). Columns 1 and 2 indicate the effects of the two different proxies for the degrees of competition variables (CR4 and $\mathrm{HHI}$ ) and the dummy variable on the variance of loan growth. As regards NPLs variables, the findings show, in both cases, a negative impact on bank lending behavior at the $1 \%$ level. This confirms the findings of Keeton (1999), Berrospide and Edge (2010), Alhassan et al. (2013), and Cucinelli (2015), and is in line with the study's expectation. Therefore, credit risk is a major determinant of bank lending behavior, as well as showing a negative significant impact. In the downturn, rising NPLs engenders greater caution among banks and leads to the tightening of credit extension. Moreover, high NPL ratios also have negative implications for banks' capital, limiting their access to financing.

The empirical results also indicate that the lagged dependent variable has a positive sign and is statistically significant in all specifications. Overall, banks' lending behavior depends significantly on ROA, ETA, TA, LDR, HHI or CR4, INF, and GDP. First, a positive coefficient of the effect on ROA suggests that more profitable banks have fewer constraints and are less risk-averse, therefore being more likely to expand their loan portfolios. Second, the findings also show the positive coefficient of the impact on LDR, as banks with higher loan-to-deposit ratios have more capacity to manage risks and develop faster than others. Third, ETA also shows a statistically significant and positive effect, implying that low-capitalized banks in Vietnam must limit their credit and focus on improving their capitalization during the study period. A positive effect of the competition on $\mathrm{HHI}$ 
and CR4 shows that banks increase lending in the higher concentrated industry.

With regard to the other variables, GDP growth shows a positive impact on bank lending behavior, while inflation displays a negative impact. During an economic upturn, firms' cash flows are improved, and banks have an incentive to extend credit to borrowers. On the contrary, a recessionary period not only increases the default risk but also lowers loan demand. Finally, regarding the dummy variable, the findings suggest that there is no difference between ownership and lending behavior among Vietnamese commercial banks.

\section{Table 6}

Estimation results of non-performing loans and lending behavior

\begin{tabular}{|c|c|c|}
\hline & \multicolumn{2}{|c|}{ LGR } \\
\hline & (1) & (2) \\
\hline L.LGR & $0.2922 * * *(0.0285)$ & $0.1873 * * *(0.0018)$ \\
\hline NPL & $-0.2338^{* * *}(0.1143)$ & $-0.2142 * * *(0.8120)$ \\
\hline ROA & $0.0384 * * *(0.1080)$ & $0.0515^{* * *}(0.1411)$ \\
\hline ETA & $0.5492 * * *(0.1609)$ & $0.0540 * * *(0.1754)$ \\
\hline TA & $-0.2721^{* * *}(0.6518)$ & $-0.0061 * * *(0.4215)$ \\
\hline LDR & $0.0264 *(0.1353)$ & $0.0040 * * *(0.1287)$ \\
\hline OWN1 & & $-0.1241(0.1721)$ \\
\hline OWN2 & & $0.1766(0.3343)$ \\
\hline OWN3 & & $0.1288(0.2811)$ \\
\hline HHI & $0.1291 * * *(0.4375)$ & \\
\hline CR4 & & $0.2210^{* * *}(0.1632)$ \\
\hline GDP & $0.0390 * * *(0.4286)$ & $0.0080^{* * *}(0.4885)$ \\
\hline INF & $-0.0020^{* * *}(0.3479)$ & $-0.0030^{* * *}(0.2290)$ \\
\hline CONS. & $-0.0250^{* * *}(0.5632)$ & $-0.4840^{* * *}(0.4363)$ \\
\hline No. of Obs. & 323 & 323 \\
\hline Banks & 34 & 34 \\
\hline No. of iv. & 21 & 27 \\
\hline
\end{tabular}


LGR

(1)

(2)

\begin{tabular}{lll}
\hline Pro>chi2 & 0.000 & 0.000 \\
Hansen test & 0.522 & 0.328 \\
AR(1) & 0.039 & 0.047 \\
AR(2) & 0.468 & 0.523
\end{tabular}

Notes: $* * *, * *, * *$ and $* *$ denote significance levels of $1 \%, 5 \%$, and $10 \%$ respectively. Standard errors are in parentheses. The HHI variable is removed from specifications (1) and (2) to avoid the multicollinearity problem as it is highly correlated with CR4.

\section{Conclusion and recommendations}

This study investigates the impact of NPLs on bank profitability and lending behavior based on sample of 34 Vietnamese commercial banks. By applying the dynamic panel data techniques along with SystemGMM estimation, the empirical results provide some evidence to confirm that the NPL has negative effects of bank profitability and lending behavior. The deterioration in asset quality thus reduces profitability and lending activities. Higher levels of NPLs are found to reduce banks' effort to enhance loan offers. We also find that high-capitalized banks have higher profitability and loan growth.

A few substantial policy implications emerge from these empirical results. First, the negative relationship between NPLs and profitability suggests that the regulator should apply closer screening and monitoring of the risk of loan default in order to maximize profits. In addition, higher capital ratios give more incentive to increase lending than lower capital ratios.
Thus, implementation of risk-based capital requirement can help to prevent risk-taking behavior by soothing over-heated lending behavior for high-risk banks. The long-term strategies require Vietnamese commercial banks to take precautions against NPLs such as completing credit policies in accordance with international standards, which is considered a prerequisite for uniform and close compliance of the widely accepted policies. It is also crucial to improve management mechanism, control risks, and draw on foreign banks' experience in implementing credit analysis based on cash flow and monitoring borrowers' solvency.

The shortcoming of this study is that it cannot classify Vietnamese banks into identified groups based on their size or growth rate as well as failing to categorize non-performing loans by type. Further study thus need examine the impacts of NPLs on profitability and lending behavior according to specific types of NPLs or in association with bank size or different levels of banks' growth on the market 


\section{References}

Akhavein, J. D., Swamy, P. V., \& Taubman, S. B. (1997). A general method of deriving the efficiencies of banks from a profit function. Journal of Productivity Analysis, 8(1), 71-93.

Alhassan, A. L., Brobbey, F. O., \& Aamoah, M. E. (2013). Does asset quality persist on bank lending behavior? Empirical evidence from Ghana. Global Journal of Management and Business Research Finance, 13(4), 1-8.

Altunbas, Y., Liu, H., Molyneux, P., \& Seth, R. (2000). Efficiency and risk in Japanese banking. Journal of Banking \& Finance, 24(10), 1605-1628.

Amador, S., Gòmez-Gonzàlez, E., \& Pabon, M. (2013). Loans growth and banks' risk: New evidence. Borradores de Economia, 763.

Arellano, M., \& Bover, O. (1995). Another look at the instrumental-variable estimation of errorcomponents. Journal of Econometrics, 68(1), 29-52.

Athanasoglou, P. P., Brissimis, S. N., \& Delis, M. D. (2008). Bank-specific, industry-specific and macroeconomic determinants of bank profitability. Journal of International Financial Markets, Institutions and Money, 18(2), 121-136.

Blundell, R., \& Bond, S. (2000). GMM estimation with persistent panel data: An application to production functions. Econometric Reviews, 19(3), 321-340.

Banker, R., Chang, H., \& Lee, S. (2010), Differential impact of Korean banking system reforms on bank productivity. Journal of Banking \& Finance, 34(7), 1450-1460.

Berger, A. N., \& DeYoung, R. (1997). Problem loans and cost efficiency in commercial banks. Journal of Banking \& Finance, 21, 849-870.

Bernanke, B., Gertler, M., \& Gilchrist, S. (1994). The financial accelerator and the flight to quality. Retrieved March 5, 2016 from http://www.nber.org/papers/w4789.pdf

Berger, N., \& Humphrey, B. (1992). Measurement and efficiency issues of commercial banking. In Z. Griliches (Ed.), Output measurement in the services sectors (pp. 245-279). National Bureau of Economic Research Studies in Income and Wealth. University of Chicago Press, Chicago.

Berger, A. N., \& Udell, G. F. (2004). The institutional memory hypothesis and the procyclicality of bank lending behavior. Journal of Financial Intermediation, 13(4), 458-495.

Berrospide, J. M., \& Edge, R. M. (2010). The effects of bank capital on lending: What do we know, and what does it mean? Financial and Economics Discussion Series. Federal Reserve Board. Washington, DC.

Borio, C., \& Drehmann, M. (2009). Assessing the risk of banking crises-revisited. BIS Quarterly Review, 29-46.

Borio, C., Furfine, C., \& Lowe, P. (2002). Procyclicality of the financial system and financial stability: Issue and policy options. BIS Working Papers 1, 1-57

Casu, B., \& Girardone, C. (2006). Bank competition, concentration and efficiency in the single European market. The Manchester School, 74(4), 441-468.

Cucinelli, D. (2015). The impact of non-performing loans on bank lending behavior: Evidence from 
the Italian banking sector. Eurasian Journal of Business and Economics, 8(16), 59-71.

Demirgu"c-Kunt, A., \& Huizinga, H. (1999). Determinants of commercial bank interest margins and profitability: Some international evidence. The World Bank Economic Review, 13(2), 379-408.

Doytch, N., \& Uctum, M. (2011). Does the worldwide shift of FDI from manufacturing to services accelerate economic growth? A GMM estimation study. Journal of International Money and Finance, 30(3), 410-427.

Driffill, J., Psaradakis, Z., \& Sola, M. (1998). Testing the expectations hypothesis of the term structure using instrumental variables. International Journal of Finance and Economics, 3(4), 321-325.

Fan, L., \& Shaffer, S. (2004). Efficiency versus risk in large domestic US banks. Managerial Finance, 30(9), 1-19.

Foos, D., Norden, L., \& Weber, M. (2010). Loan growth and riskiness of banks. Journal of Banking \& Finance, 34(12), 2929-2940.

Fu, X., \& Heffernan, S. (2009). The effects of reform on China's bank structure and performance. Journal of Banking \& Finance, 33(1), 39-52.

García-Herrero, A., Gavilá, S., \& Santabárbara, D. (2009). What explains the low profitability of Chinese banks? Journal of Banking \& Finance, 33(11), 2080-2092.

Girardone, C., Molyneux, P., \& Gardener, E. P. (2004). Analysing the determinants of bank efficiency: The case of Italian banks. Applied Economics, 36(3), 215-227.

Goddard, J., Molyneux, P., \& Wilson, S. (2004). The profitability of European banks: A crosssectional and dynamic panel analysis. The Manchester School, 72(3), 363-381.

Hannan, T. H., \& Berger, A. N. (1991). The rigidity of prices: Evidence from the banking industry. American Economic Review, 81(4), 938-945.

Heggestad, A. A. (1977). The competitive condition of US banking markets and the impact of structural reform. Journal of Finance, 32(4), 649-661.

Hou, Y., \& Dickinson, D. (2007). The non-performing loans: Some bank-level evidences. Research Conference on Safety and Efficiency of the Financial System, August 2007.

Hughes, P., \& Mester, J. (1993). A quality and risk-adjusted cost function for banks: Evidence on the 'too-big-to-fail' doctrine. Journal of Productivity Analysis, 4, 293-315.

Karim, M. Z. A. (2010). Bank efficiency and non-performing loans: Evidence from Malaysia and Singapore, Prague Economic Papers, 2, 118-132.

Karminsky, A. M., \& Kostrov, A. (2014). The probability of default in Russian banking. Eurasian Economic Review, 4(1), 81-98.

Kiyotaki, N., \& Moore, J. (1995). Credit cycles. Retrieved March 10, 2016 from http://www.nber.org/papers/w5083

Keeton, W. R. (1999). Does faster loan growth lead to higher loan losses? Economic Review, 84(2), 57-75.

Kwan, S., \& Eisenbeis, R. (1995). An analysis of inefficiencies in banking. Journal of Banking and Finance, 19(3-4), 733-734.

Le, C. (2016). Macro-financial linkages and bank behaviour: Evidence from the second-round effects 
of the global financial crisis on East Asia. Retrieved 30 May, 2016 from https://www.researchgate.net/publication/295084778

Lee, C., \& Hsieh, F. (2013). Beyond bank competition and profitability: Can moral hazard tell us more? Journal of Financial Services Research, 44(1), 87-109.

Lu, D., Thangavelu, S. M., \& Hu, Q. (2005). Biased lending and non-performing loans in China's banking sector. Journal of Development Studies, 41(6), 1071-1091.

Marius, A. (2011). The determinants of bank efficiency and productivity growth in the Central and Eastern European banking systems. Eastern European Economics, 49(6), 38-59.

Neumark, D., \& Sharpe, S. A. (1992). Market structure and the nature of price rigidity: Evidence from the market for consumer deposits. Quarterly Journal of Economics, 107(2), 657-680.

Phạm, T. (2013). Effect of bad debts on bank profitability. Economic Research, 424, 34-39.

Short, K. (1979). The relation between commercial bank profit rates and banking concentration in Canada, Western Europe and Japan. Journal of Banking and Finance, 3(4), 209-219.

Tomak, S. (2013). Determinants of commercial bank' lending behavior: Evidence from Turkey. Asian Journal of Empirical Research, 3(8), 933-943.

Trujillo-Ponce, A. (2013). What determines the profitability of banks? Evidence from Spain. Accounting \& Finance, 53(2), 561-586.

Windmeijer, F. (2005). A finite sample correction for the variance of linear efficient two-step GMM estimators. Journal of Econometrics, 126(1), 25-51.

Wheelock, C., \& Wilson, P. W. (1995). Explaining bank failures: Deposit insurance, regulation, and efficiency. Review of Economics and Statistics, 77, 689-700.

\section{Appendix}

The sample of Vietnamese banks includes An Binh Commercial Bank, Asia Commercial Bank, Vietnam Bank For Agriculture And Rural Development, Bank For Investment And Development Of Vietnam, Viet Capital Commercial Joint Stock Bank, Vietnam Bank For Industry And Trade, Eastern Asia Commercial Joint Stock Bank, Vietnam Export Import Commercial Joint Stock Bank, Housing Development Commercial Joint Stock Bank, Kien Long Commercial Joint Stock Bank, Lienviet Post Commercial Joint Stock Bank, Military Commercial Joint Stock Bank, Mekong Development Joint Stock Commercial Bank, Mekong Housing Commercial Bank, Maritime Commercial Joint Stock Bank, Southern Commercial Joint Stock Bank, BACA Commercial Joint Stock Bank, Orient Commercial Joint Stock Bank, OCEAN Commercial Joint Stock Bank, Petrolimex Group Commercial Joint Stock Bank, Vietnam Public Bank, Southern Commercial Joint Stock Bank, Sai Gon Joint Stock Commercial Bank, Southeast Asia Commercial Joint Stock Bank, Saigon Bank For Industry \& Trade, Saigon-Hanoi Commercial Joint Stock Bank, Sai Gon Thuong Tin Commercial Joint-Stock Bank, Vietnam Technological And Commercial Joint Stock Bank, Tien Phong Joint Stock Commercial Bank, National Joint Stock Commercial Bank, Viet A 
Commercial Joint Stock Bank, Joint Stock Commercial Bank For Foreign Trade Of Vietnam, Vietnam International Commercial Joint Stock Bank, Vietnam Prosperity Commercial Joint Stock Bank. 